\title{
Problematic familial alcohol use and heavy episodic drinking among upper secondary students: a moderator analysis of teacher-rated school ethos
}

\author{
Gabriella Olsson ${ }^{*}$, , Sara Brolin Låftman, Joakim Wahlström and Bitte Modin
}

\begin{abstract}
Objective: Building on findings reported in a previous publication, the objective of this study is to explore if teacherrated indicators of school ethos modify the association between problematic familial alcohol use and heavy episodic drinking among upper secondary students. Data were based on combined information from two separate surveys conducted in 2016 among 4709 students and 1061 teachers in 46 Stockholm upper secondary schools, with linked school-level information from administrative registers. Multilevel binary logistic regression analyses were performed.

Results: Problematic familial alcohol use was associated with an increased likelihood of heavy episodic drinking among upper secondary students (OR 1.36, 95\% Cl 1.12-1.65). Cross-level interactions revealed that the association was weaker among students attending schools with higher levels of teacher-rated ethos. This was true for overall school ethos (OR $0.79,95 \% \mathrm{Cl} 0.65-0.97$ ) and for four of five studied sub-dimensions of ethos: staff stability (OR 0.78, 95\% Cl 0.65-0.95); teacher morale (OR 0.79, 95\% Cl 0.65-0.97); student focus (OR 0.80, 95\% Cl 0.65-0.97); and academic atmosphere (OR $0.79,95 \% \mathrm{Cl} 0.65-0.96)$. The sub-dimension "structure and order for dealing with unwanted behaviour" did however not moderate the association between problematic familial alcohol use and heavy episodic drinking (OR 0.95, 95\% Cl 0.77-1.18).
\end{abstract}

Keywords: Binge drinking, Adolescents, School, Effective schools, Contextual

\section{Introduction}

Heavy episodic drinking (HED), often defined as consuming at least six alcoholic drinks on one occasion at least monthly [1], during adolescence has been linked to injuries [2] and a range of negative social and behavioural outcomes in youth [3] and in adulthood [4]. Among those with early onset [5] and in more vulnerable populations $[4,6]$, the risk for long-term consequences seems to be particularly elevated. A key risk factor for excessive drinking in youth is problematic familial alcohol use;

${ }^{*}$ Correspondence: gabriella.olsson@su.se

Department of Public Health Sciences, Centre for Health Equity Studies

(CHESS), Stockholm University, 10691 Stockholm, Sweden both in terms of serious and long-term parental alcohol problems [7] and parental drinking at lower levels of risk drinking $[8,9]$. Modelling of familial behaviours, impaired parenting practices [10], but also inherited psychological and biological personality traits that in interaction with the environmental stressors in the family put individuals at greater risk of developing problematic drinking are some of the suggested mechanisms [7].

Previous research concerned with the impact of problematic drinking in the family on youth alcohol consumption $[8,9]$ has mainly sought for risk and protective factors in the context of the family, but more rarely explored how conditions in the family interact with conditions in other social and institutional 
settings. Yet, it is reasonable to assume that such interacting effects exists [11]. Research into school effects does suggest that conditions in school are linked to student risk behaviours, including alcohol consumption [12-14]. In addition, school effectiveness research has long showed that qualities of the school per se matter for students' academic performance and behaviours, regardless of the students' own background [15]. Yet most of the research conducted in this field has been concerned with the direct effect of conditions in school on youth behaviours, while less research has been devoted to exploring the compensatory role of schools. Existing studies do however suggest that this is a relevant inquiry that ought to be further explored [16-18].

The current study builds on, and extends, the analyses reported in a study by Olsson et al. [19] which was based on the assumption that conditions in school may buffer against problematic conditions in the family. Olsson et al. [19] examined the association between familial problematic drinking and heavy drinking among ninth grade students (age 15-16 years) and, more specifically, the moderating role of schools' level of teacher-reported student focus. Student focus can be understood as one sub-dimension of school ethos that refers to positive teacher-student relationships. In line with previous research [9, 10, 20-22], Olsson et al. [19] reported that there was a positive association between familial problematic drinking and heavy drinking among students. However, the association was weaker among students attending schools with higher teacher ratings of student focus, suggesting a protective effect.

The present paper is based on the same data material as the study by Olsson et al. [19], but extends it in two ways, namely by analysing the association between problematic familial alcohol use and offspring drinking among older students, and by examining the potentially moderating role of teacher-rated school ethos in a broader sense.

The aim of the current study is to explore if teacherrated indicators of school ethos modify the association between problematic familial alcohol use and heavy episodic drinking among upper secondary students, focusing both on an overall measure of school ethos and on five different sub-dimensions of school ethos: (1) staff stability; (2) teacher morale; (3) structure and order for dealing with unwanted behavior; (4) student focus; and (5) academic atmosphere [23]. Building on the result of the study by us [19], two hypotheses were formulated:

H1. Problematic drinking in the family is associated with increased likelihood of heavy episodic drinking in the offspring.

H2. A strong teacher rated school ethos may moderate this association.

\section{Main text}

\section{Data material and methods}

The data was drawn from two cross-sectional surveys performed in 2016: the Stockholm School Survey (SSS) and the Stockholm Teacher Survey (STS), which were combined. In addition, school-level official register information from the Swedish National Agency for Education has been merged with the data.

The SSS is carried out every other year by Stockholm municipality among students in grade 9 of compulsory school (ages 15-16 years) and in grade 2 of upper secondary school (ages 17-18 years) in all public schools and in a large number of independent schools in Stockholm. Students complete the questionnaires in the classroom. The response rate for the 2016 survey has been estimated to 78 per cent [24].

The STS was performed among teachers in 2014 and in 2016 as part of a research project at Stockholm University. Teachers in schools whose students took part in the SSS were invited to participate in a web survey. In 2014, the STS was performed among teachers in the senior-level schools that took part in the SSS, and in 2016 it was performed among teachers in both senior-level and upper secondary schools that participated in the SSS. School-level measures of teacher ratings of, e.g., school ethos and school leadership were formed by taking the mean values of each school. These measures were subsequently linked to the SSS student level data. The response rate among upper secondary teachers was $58 \%[23,25]$.

The present study was based on data from 2016: the SSS collected among students in the second grade of upper secondary school (17-18 years), school-level information from the STS, and official register information on schools from the Swedish National Agency for Education. The study sample includes responses from 4709 students and 1061 teachers distributed across 46 upper secondary schools. More information on the data material is found elsewhere [23, 25].

\section{Ethics}

According to a decision by the Regional Ethical Review Board of Stockholm (2010/241-31/5), data from the Stockholm School Survey are not subject to consideration for ethical approval since the questionnaires are completed anonymously with no information on personal identification. The Regional Ethical Review Board of Stockholm has granted ethical approval for the Stockholm Teacher Survey (2015/1827-31/5).

\section{Measures}

Heavy episodic drinking was assessed by one question in the SSS: "How often do you drink the following amounts of alcohol at any one time: $18 \mathrm{cl}$ spirits or 
a whole bottle of wine or four large bottles of strong cider/alcopop or four cans of class III beer or six cans of class II beer?". The response categories were "Do not drink alcohol", "Never", "Very seldom", "A few times each year", "A few times a month", "A couple of times a month", and "A few times a week". The item was dichotomised by classifying students who answered "A few times a month" or more often as engaging in heavy episodic drinking. This is an established measure, used in alcohol surveys among youth in Sweden since the 1970s $[24,26]$ and in previous research $[27,28]$. It is deemed roughly equivalent [28] to WHO [1] definition of HED as consuming at least $60 \mathrm{~g}$ or more of pure alcohol on at least one occasion in the past 30 days. A consumption of $60 \mathrm{~g}$ of pure alcohol corresponds approximately to five standard alcoholic drinks [1].

Problematic familial alcohol use was measured by one question in the SSS: "Do you think someone in your family drinks too much alcohol?" The response categories were "Yes", "No", and "Don't know". Those who answered "Don't know" were excluded from the analysis. The same question was used in the study by Olsson et al. [19].

School ethos was captured by an index of 17 items (Cronbach's alpha $=0.94$ ) [25]. This overall measure of ethos was also divided into five sub-dimensions: (1) staff stability, referring to the level of sick-leave among teachers, staff turnover, and the frequency of substitute teachers at the school (3 items, Cronbach's alpha $=0.55)$; (2) teacher morale, referring to whether the teachers have a strong work ethic, work with great enthusiasm, take pride in their school, and feel confident as classroom leaders ( 4 items; Cronbach's alpha $=0.93$ ); (3) structure and order for dealing with unwanted behaviour, referring to the schools' value system, whether the school actively works on issues such as violence, bullying and harassment among students, whether teachers feel confident about what they may and may not do if violent situations arise among students, and whether the rules for order and conduct are clear at the school (4 items, Cronbach's alpha $=0.92)$; (4) student focus among teachers, referring to teachers' positive feedback to, and high expectations of, the students, whether the teachers take time with students even if they want to discuss something other than schoolwork, and whether the students are treated with respect ( 4 items, Cronbach's alpha $=0.79$ ); and (5) academic atmosphere, referring to the extent to which the school provides a stimulating learning environment and whether the students' motivation is a stimulating part of work ( 2 items, Cronbach's alpha $=0.89$ ). The measures of overall school ethos and of the five subdimensions were all standardised (mean $=0$; standard deviation $=1$ ). The measures have been used in prior research [23].
A number of control variables capturing sociodemographic characteristics were also included. At the student level, we controlled for gender, family structure, parental university education, and migration background, based on information from the SSS. At the school level, we controlled for the proportion of students with university educated parents and the proportion of students with a foreign background, based on administrative register information.

\section{Statistical method}

The statistical method used was multilevel modelling. Two-level binary logistic regression models were estimated using the "meqrlogit" command in Stata, version 15 [29]. Results are presented as odds ratios (OR) with 95\% Confidence Intervals (95\% CI).

\section{Results}

Descriptive statistics are presented in Table 1. In our sample, $29.8 \%$ of the students reported heavy episodic drinking and $12.3 \%$ reported problematic familial alcohol use. The sample consisted of about equal shares of boys and girls. Around two thirds lived with two parents in the same household and about a third did not. About two thirds had at least one parent with university education and 9\% had lived in Sweden for less than ten years. Mean value, standard deviation, range of all school-level variables and possible scale range within brackets are presented at the bottom of Table 1 .

A series of two-level binary logistic regression analyses with heavy episodic drinking as the dependent variable are presented in Table 2. According to the empty model, $11.7 \%$ of the variation in heavy episodic drinking could be attributed to the school level. Model 1 includes studentlevel variables. Those who reported problematic familial alcohol use had a higher likelihood of reporting heavy episodic drinking compared with those who did not report problematic familial alcohol use (OR 1.36, 95\% CI $1.12-1.65)$. Furthermore, girls were less likely than boys to have engaged in heavy episodic drinking (OR 0.77, 95\% CI 0.67-0.88). Students not living with two parents in the same household had a greater likelihood of having reported heavy episodic drinking (OR 1.38, 95\% CI 1.20$1.58)$, as were students who reported having at least one university-educated parent (OR 1.42, 95\% CI 1.22-1.65). Students who had lived less than ten years in Sweden had a lower likelihood of reporting heavy episodic drinking (OR 0.31, 95\% CI 0.22-0.44). Model 2 added overall school ethos, which showed a positive but not statistically significant association with heavy episodic drinking at the student level (OR 1.16, 95\% CI 0.96-1.39). Next, the school proportion of students whose parent(s) had post-secondary education, and the school proportion of 
Table 1 Descriptives

\begin{tabular}{|c|c|c|c|c|}
\hline & $\mathbf{n}$ & $\%$ & & \\
\hline \multicolumn{5}{|l|}{ Student level } \\
\hline Heavy episodic drinking & 1405 & 29.8 & & \\
\hline \multicolumn{5}{|l|}{ Problematic familial alcohol use } \\
\hline No & 4128 & 87.7 & & \\
\hline Yes & 581 & 12.3 & & \\
\hline \multicolumn{5}{|l|}{ Gender } \\
\hline Boy & 2177 & 46.2 & & \\
\hline Girl & 2532 & 53.8 & & \\
\hline \multicolumn{5}{|l|}{ Family structure } \\
\hline Two-parent household & 3025 & 64.2 & & \\
\hline Other & 1684 & 35.8 & & \\
\hline \multicolumn{5}{|l|}{ Parental university education } \\
\hline No or not known & 1537 & 32.6 & & \\
\hline At least one parent & 3172 & 67.4 & & \\
\hline \multicolumn{5}{|l|}{ Migration background } \\
\hline$\geq 10$ years in Sweden & 4285 & 91.0 & & \\
\hline \multirow[t]{2}{*}{$<10$ years in Sweden } & 424 & 9.0 & & \\
\hline & Mean & SD & Min. & Max. \\
\hline \multicolumn{5}{|l|}{ School level (scale points) } \\
\hline Overall school ethos (0-28.9) & 62.7 & 6.1 & 46.4 & 75.3 \\
\hline \multicolumn{5}{|l|}{ Sub-dimensions of ethos } \\
\hline Staff stability (0-6.0) & 8.8 & 1.3 & 4.7 & 11.7 \\
\hline Teacher morale (0-7.3) & 15.8 & 1.7 & 12.0 & 19.3 \\
\hline Structure and order (0-9.0) & 14.3 & 1.6 & 9.3 & 18.3 \\
\hline Student focus $(0-5.1)$ & 16.6 & 1.1 & 13.9 & 19.0 \\
\hline Academic atmosphere $(0-4.8)$ & 7.3 & 1.4 & 4.6 & 9.4 \\
\hline $\begin{array}{l}\% \text { students with at least one parent with university education } \\
(0-100)\end{array}$ & 52.0 & 25.1 & 7.0 & 86.3 \\
\hline$\%$ students with a foreign background (0-100) & 40.9 & 21.4 & 6.0 & 95.7 \\
\hline
\end{tabular}

students with a foreign background were added (Model $3)$, but neither of these were statistically significant. Finally, in Model 4, we included the cross-level interaction between problematic familial alcohol use and overall school ethos, which was statistically significant (OR 0.79, 95\% CI 0.65-0.97, $\mathrm{p}=0.022$ ).

To further assess the cross-level interactions between problematic familial alcohol use and different sub-dimensions of school ethos, we performed a set of analyses where we included one sub-dimension at a time as well as the cross-level interaction between the sub-dimension and problematic familial alcohol use. The estimates of the cross-level interactions from five separate two-level binary regression analyses are displayed in Table 3 . The results show that for all sub-dimensions of school ethos except structure and order, there were statistically significant cross-level interactions with problematic familial alcohol use, demonstrating a weaker association with heavy episode drinking among students attending schools with higher levels of teacher-rated ethos.

\section{Discussion and conclusion}

This study sheds light on the potential of the school to counteract problematic conditions in the family in relation to adolescent health risk behaviours. The findings corroborate previous research which has shown that parental drinking is linked with an increased likelihood of alcohol use in the offspring [9, 10, 20-22]. Furthermore, the study showed that teacher-rated school ethos had a moderating effect in that the association was weaker among students attending schools with higher teacher ratings of the ethos. This was true for overall school ethos and for four of five studied sub-dimensions of ethos: staff stability; teacher morale; student focus; and academic atmosphere. By suggesting that a strong school ethos has the potential to counteract 
Table 2 Two-level binary logistic regression of heavy episodic drinking

\begin{tabular}{|c|c|c|c|c|c|c|c|c|c|}
\hline & \multirow[t]{2}{*}{ Empty model } & \multicolumn{2}{|c|}{ Model 1} & \multicolumn{2}{|c|}{ Model 2} & \multicolumn{2}{|c|}{ Model 3} & \multicolumn{2}{|c|}{ Model 4} \\
\hline & & OR & $95 \% \mathrm{Cl}$ & OR & $95 \% \mathrm{Cl}$ & OR & $95 \% \mathrm{Cl}$ & OR & $95 \% \mathrm{Cl}$ \\
\hline \multicolumn{10}{|l|}{ Student level } \\
\hline \multicolumn{10}{|l|}{ Problematic familial alcohol use } \\
\hline No (ref.) & & 1.00 & - & 1.00 & - & 1.00 & - & 1.00 & - \\
\hline Yes & & $1.36^{* *}$ & $1.12-1.65$ & $1.36^{* *}$ & $1.12-1.65$ & $1.36^{* *}$ & $1.12-1.65$ & $1.38^{* *}$ & $1.13-1.67$ \\
\hline \multicolumn{10}{|l|}{ Gender } \\
\hline Boy (ref.) & & 1.00 & - & 1.00 & - & 1.00 & - & 1.00 & - \\
\hline Girl & & $0.77^{* * *}$ & $0.67-0.88$ & $0.77^{* * *}$ & $0.67-0.88$ & $0.77^{* * *}$ & $0.67-0.89$ & $0.77^{* * *}$ & $0.67-0.89$ \\
\hline \multicolumn{10}{|l|}{ Family structure } \\
\hline Two-parent household (ref.) & & 1.00 & - & 1.00 & - & 1.00 & - & 1.00 & - \\
\hline Other & & $1.38^{* * *}$ & $1.20-1.58$ & $1.38^{* * *}$ & $1.20-1.59$ & $1.38^{* * *}$ & $1.20-1.58$ & $1.38^{* * *}$ & $1.20-1.59$ \\
\hline \multicolumn{10}{|l|}{ Parental university education } \\
\hline No or not known (ref.) & & 1.00 & - & 1.00 & - & 1.00 & - & 1.00 & - \\
\hline At least one parent & & $1.42^{* * *}$ & $1.22-1.65$ & $1.41^{* * *}$ & $1.21-1.64$ & $1.41^{* * *}$ & $1.21-1.65$ & $1.41^{* * *}$ & $1.20-1.64$ \\
\hline \multicolumn{10}{|l|}{ Migration background } \\
\hline$\geq 10$ years in Sweden (ref.) & & 1.00 & - & 1.00 & - & 1.00 & - & 1.00 & - \\
\hline$<10$ years in Sweden & & $0.31^{* * *}$ & $0.22-0.44$ & $0.31^{* * *}$ & $0.22-0.44$ & $0.31^{* * *}$ & $0.22-0.44$ & $0.31^{* * *}$ & $0.22-0.44$ \\
\hline \multicolumn{10}{|l|}{ School level } \\
\hline Overall school ethos & & & & 1.16 & $0.96-1.39$ & 1.15 & $0.94-1.40$ & 1.19 & $0.97-1.45$ \\
\hline $\begin{array}{l}\% \text { students with parents with post- } \\
\text { secondary education }\end{array}$ & & & & & & 1.00 & $0.99-1.01$ & 1.00 & $0.99-1.01$ \\
\hline$\%$ students with a foreign background & & & & & & 1.00 & $0.99-1.01$ & 1.00 & $0.99-1.01$ \\
\hline \multicolumn{10}{|l|}{ Cross-level interaction } \\
\hline Problematic familial alcohol use* & & & & & & & & $0.79^{*}$ & $0.65-0.97$ \\
\hline \multicolumn{10}{|l|}{ Overall school ethos } \\
\hline Intraclass Correlation (ICC) (\%) & $11.7^{* * *}$ & $9.5^{* * *}$ & & $8.9^{* * *}$ & & $8.8^{* * *}$ & & $8.7^{* * *}$ & \\
\hline
\end{tabular}

$\mathrm{n}=4709$ students in 46 upper secondary schools

${ }^{* * *} \mathrm{p}<0.001 ;{ }^{* *} \mathrm{p}<0.01 ;{ }^{*} \mathrm{p}<0.05$

Table 3 Cross-level interactions between problematic familial alcohol use and one sub-dimension of ethos at a time

\begin{tabular}{lll}
\hline Cross-level interactions & OR $^{\mathbf{a}}$ & $\mathbf{9 5 \% ~ C l}$ \\
\hline $\begin{array}{l}\text { Problematic familial alcohol use* } \\
\text { Staff stability }\end{array}$ & $0.78^{*}$ & $0.65-0.95$ \\
$\begin{array}{l}\text { Problematic familial alcohol use* } \\
\text { Teacher morale }\end{array}$ & $0.79^{*}$ & $0.65-0.97$ \\
$\begin{array}{l}\text { Problematic familial alcohol use } \\
\text { Structure and order }\end{array}$ & 0.95 & $0.77-1.18$ \\
$\begin{array}{l}\text { Problematic familial alcohol use } \\
\text { Student focus }\end{array}$ & $0.80^{*}$ & $0.65-0.97$ \\
$\begin{array}{l}\text { Problematic familial alcohol use* } \\
\text { Academic atmosphere }\end{array}$ & $0.79^{*}$ & $0.65-0.96$ \\
\hline
\end{tabular}

$\mathrm{n}=4709$ students in 46 upper secondary schools

a Odds ratios from two-level binary logistic regression analyses of heavy episodic drinking. All models are adjusted for gender, family structure, parental university education, and migration background at the student level, and for the proportion of students with parents with post-secondary education and proportion of students with a foreign background at the school level

* $\mathrm{p}<0.05$ poor conditions in the family in relation to student alcohol use, the result extends the findings of Olsson et al. [19]. The result is also in line with other available studies that have explored and found evidence of moderating effect of schools on youth problem behaviours [16, 30,31]. However, it should be noted that the association between problematic familial alcohol use and heavy episodic drinking was not moderated by the sub-dimension structure and order for dealing with unwanted behaviour. Although this may seem somewhat counterintuitive, the result is in line with that of other studies [13, 23]. As suggested in these, articulated values for structure and order may not be effective means of reducing substance use in isolation from broader changes to the school environment. Hence, singled out from the other sub-dimensions of school ethos a school environment characterised by structure and order cannot be expected to compensate for risk laden parenting environments. Broader changes to the school ethos has to be put in place first. 
Yet, taken together, the findings lend further support to the assumption that a favorable school environment may buffer against the potentially negative effects of problematic conditions in the family. Efforts placed at creating a school environment characterised by a strong school ethos in terms of staff stability, a strong teacher morale as well as a strong student and academic focus could thus be one way of avoiding problematic drinking patterns in the family to be transferred to adolescents. Making school leaders and policy makers aware of the potential of such broader interventions to prevent health risk behaviours, notably alcohol consumption among youth at risk, thus seems to be an important task. In addition, as suggested by Wiefferink et al. [32], looking beyond specific health behaviour directed policies, would also reduce the risk of teachers and school leaders becoming overloaded by extracurricular activities and continuous innovations aimed at promoting student health and well-being.

\section{Limitations}

The main limitation is the cross-sectional design of the study, which inhibits interpretations about causality with support in the data. Relatedly, we are not able to fully control for the selection of students into schools. There may be factors other than those accounted for in our study, that affect both students' likelihood of attending schools with a certain level of ethos and their likelihood of engaging in heavy episodic drinking. There is also uncertainty regarding the validity of the measure of problematic familial alcohol use since information is obtained from students only, not parents or other family members. That data is based on selfreports may also, in particular in relation to questions about less socially acceptable behaviour, be associated with under- and over-reporting. However, the data has been sorted and questionnaires where for instance the reported amount of alcohol consumed was deemed as unreliable have been discarded [33]. Another limitation concerns the relatively low response rate among teachers (58\%) and the scarce possibilities of checking any systematic bias among the non-responders. Finally, since the study was conducted in Stockholm municipality, the generalisability of the findings is limited.

\section{Abbreviations \\ 95\% Cl: 95\% confidence interval; ICC: Intraclass correlation; OR: Odds ratio; SSS:} Stockholm School Survey; STS: Stockholm Teacher Survey.

\section{Acknowledgements}

We are grateful to the students and the teachers who participated in the data collections. We are also grateful to the Stockholm Municipality for giving us access to data from the Stockholm School Survey.

\section{Authors' contributions}

GO and SBL designed the study. The STS data were collected in a research project headed by BM. SBL drafted a first version of the manuscript and performed the statistical analyses with GO. All authors read and approved the final manuscript.

\section{Funding}

Open access funding provided by Stockholm University. The study was financed by Systembolagets Alkoholforskningsråd (2019-0012; 2020-0047). The funder had no role in the study design, the collection, analysis or interpretation of the data, nor in the writing of the manuscript.

\section{Availability of data and materials}

The data are not publicly available. The data from the Stockholm School Survey are available from Stockholm Municipality but restrictions apply to the availability of these data, which were used under license for the current study. Data from the Stockholm School Survey are however available from Stockholm Municipality upon reasonable request. Data from the Stockholm Teacher Survey can be applied for at the Department of Public Health Sciences, Stockholm University, Sweden.

\section{Declarations}

\section{Ethics approval and consent to participate}

The Stockholm School Survey (SSS) contains no information on personal identification and is completed anonymously by the students. The Regional Ethical Review Board of Stockholm (Ref. No. 2010/241-31/5) has therefore decided that analyses of data from the SSS are not subject to consideration for ethical approval. Verbal informed consent was obtained from the students who participated. Due to the procedure of anonymous completion of the questionnaire, active written or oral consent was not applicable. The collection and analyses of the Stockholm Teacher Survey (STS) have been approved of by the Regional Ethical Review Board of Stockholm (Ref. No. 2015/1827-31/5). In accordance with the ethical permission, written informed consent was obtained from those who participated.

\section{Consent for publication}

Not applicable.

\section{Competing interests}

The authors declare that they have no competing interests.

Received: 29 March 2021 Accepted: 1 September 2021

Published online: 22 September 2021

\section{References}

1. WHO. Global Status Report on alcohol and health 2018. Geneva: World Health Organisation; 2018.

2. Gore FM, et al. Global burden of disease in young people aged 10-24 years: a systematic analysis. Lancet. 2011;377(9783):2093-102.

3. Marshall EJ. Adolescent alcohol use: risks and consequences. Alcohol Alcohol. 2014;49(2):160-4.

4. McCambridge J, McAlaney J, Rowe R. Adult consequences of late adolescent alcohol consumption: a systematic review of cohort studies. PLoS Med. 2011:8(2):e1000413.

5. Pitkänen T, Lyyra A-L, Pulkkinen L. Age of onset of drinking and the use of alcohol in adulthood: a follow-up study from age 8-42 for females and males. Addiction. 2005;100(5):652-61.

6. Gauffin K, Hemmingsson T, Hjern A. The effect of childhood socioeconomic position on alcohol-related disorders later in life: a Swedish national cohort study. J Epidemiol Community Health. 2013;67(11):932-8.

7. Johnson JL, Leff M. Children of substance abusers: overview of research findings. Pediatrics. 1999;103(Supplement 2):1085-99.

8. Rossow l, et al. Parental drinking and adverse outcomes in children: a scoping review of cohort studies. Drug Alcohol Rev. 2016;35(4):397-405. 
9. Rossow l, et al. Does parental drinking influence children's drinking? A systematic review of prospective cohort studies. Addiction. 2016;111(2):204-17

10. Latendresse SJ, et al. Parenting mechanisms in links between parents' and adolescents' alcohol use behaviors. Alcohol Clin Exp Res. 2008;32(2):322-30.

11. Bronfenbrenner U. The ecology of human development: Experiments by nature and design. Cambridge: Harvard University Press; 1979. p. 1-352.

12. Sellstrom E, Bremberg S. Is there a "school effect" on pupil outcomes? A review of multilevel studies. J Epidemiol Community Health. 2006;60(2):149-55.

13. Bonell $\mathrm{C}$, et al. The effects of the school environment on student health: a systematic review of multi-level studies. Health Place. 2013;21:180-91.

14. Shackleton $\mathrm{N}$, et al. Systematic review of reviews of observational studies of school-level effects on sexual health, violence and substance use. Health Place. 2016;39:168-76.

15. Rutter M, et al. Fifteen thousand hours: secondary school effects on school children. Cambridge: Harvard University Press; 1979.

16. Eklund J, Fritzell J. Keeping delinquency at bay: The role of the school context for impulsive and sensationseeking adolescents. Eur J Criminol. 2013;11(6):682-701.

17. Crosnoe R. Social capital and the interpaly of families and schools. J Marriage Fam. 2004;66:267-80.

18. Wilcox P. An ecological approach to understanding youth smoking trajectories: problems and prospects. Addiction. 2003:98(Suppl 1):57-77.

19. Olsson G, Låftman SB, Modin B. Problematic familial alcohol use and adolescents' heavy drinking: can conditions in school compensate for the increased risk of heavy drinking among adolescents from families with problematic alcohol use? Int J Adoles Youth. 2019;24:307-18.

20. Vermeulen-Smit $E$, et al. The influence of paternal and maternal drinking patterns within two-partner families on the initiation and development of adolescent drinking. Addict Behav. 2012;37(11):1248-56.

21. Karlsson P, Magnusson C, Svensson J. Does the familial transmission of drinking patterns persist into young adulthood? A 10-year follow up. Drug Alcohol Depend. 2016;168:45-51.

22. Pisinger VSC, Bloomfield K, Tolstrup JS. Perceived parental alcohol problems, internalizing problems and impaired parent-child relationships among 71,988 young people in Denmark. Addiction. 2016;111(11):1966-74.
23. Modin B, Låftman SB, Östberg V. Teacher rated school ethos and student reported bullying - a multilevel study of upper secondary schools in Stockholm, Sweden. Int J Environ Res Public Health. 2017;14(12):1565.

24. Stockholm Municipality, Stockholmsenkäten Årsrapport 2016. Avdelningen för stadsövergripande sociala frågor. Stockholm Municipality. 2016. https://docplayer.se/106063499-Stockholmsenkaten-arsrapport-2016. html. Accessed 30 Dec 2020.

25. Kjellström J, et al. Technical report for the Teacher Survey with linkage to the Stockholm School Survey. Stockholm: Stockholm University Department of Public Health Sciences; 2018.

26. Centralförbundet för alkohol och narkotikaupplysning (CAN), Drogutvecklingen i Sverige 2014. Stockholm: CAN; 2014.

27. Thor S, Karlsson P, Landberg J. Social inequalities in harmful drinking and alcohol-related problems among swedish adolescents. Alcohol and Alcoholism. 2019;54(5):532-9.

28. Kaltenegger HC, Låftman SB, Wennberg P. Impulsivity, risk gambling, and heavy episodic drinking among adolescents: a moderator analysis of psychological health. Addict Behav Rep. 2019;10:100211.

29. StataCorp. Stata statistical software: release 15. College Station: StataCorp LLC; 2017.

30. Kirk DS. Unraveling the contextual effects on student suspension and juvenile arrest: the independent and interdependent influences of school, neighborhood, and family social controls. Criminolgy. 2009:47(2):479-517.

31. Saarento S, Garandeau CF, Salmivalli C. Classroom- and school-level contributions to bullying and victimization: a review. J Community Appl Soc Psychol. 2015;25(3):204-18.

32. Wiefferink $\mathrm{CH}$, et al. Clustering of health-related behaviors and their determinants: possible consequences for school health interventions. Prev Sci. 2006;7(2):127-49.

33. Stockholms Stads Utrednings och Statistikkontor, Stockholmsenkäten 2010_teknisk rapport. 2010. Stockholm: Stockholm Stad. https:// docplayer.se/8707851-Stockholmsenkaten-2010-teknisk-rapport.html. Accessed 12 July 2021.

\section{Publisher's Note}

Springer Nature remains neutral with regard to jurisdictional claims in published maps and institutional affiliations.
Ready to submit your research? Choose BMC and benefit from:

- fast, convenient online submission

- thorough peer review by experienced researchers in your field

- rapid publication on acceptance

- support for research data, including large and complex data types

- gold Open Access which fosters wider collaboration and increased citations

- maximum visibility for your research: over $100 \mathrm{M}$ website views per year

At $\mathrm{BMC}$, research is always in progress.

Learn more biomedcentral.com/submissions 